\title{
In order to defend science, it is necessary to make it accessible, intelligible and meaningful
}

$I^{1}$ Kenneth Rochel de Camargo Jr. I

1 Instituto de Medicina Social, Universidade do Estado do Rio de Janeiro. Rio de Janeiro-RJ, Brasil (kenneth@uerj.br). ORCID: 0000-0003-3606-5853

DOI: http://dx.doi.org/10.1590/S0103-73312018280202

For Bachelard, all sciences originate from a founding act, an epistemic rupture with common sense (BACHELARD, 1967[1938]). Boaventura de Souza Santos added to this idea the proposal of a second rupture, by means of which the new science would form a new common sense (SOUSA SANTOS, 1989). The explosion of the Internet since the end of the last century, especially with the advent of new technologies of interaction that would allow anyone with access to the network to express and communicate their ideas, as well as to interact and debate with everyone else, suggested the possibility of achieving this perspective, an admirable new world that would unfold in infinite possibilities.

Has Souza Santos's optimistic bet, however, become a reality? In spite of the desire to respond positively to this question, there is more evidence to the contrary. In "post-truth" times, ${ }^{1}$ when "bubbles" are formed on the various interactive platforms, isolating participants from alternative visions, the contribution of science is increasingly lost amid the background noise of established convictions.

\footnotetext{
1 "Adjective: Relating to or denoting circumstances in which objective facts are less influential in shaping public opinion than appeals to emotion and personal belief”. Available at: $<$ [https://en.oxforddictionaries. com/definition/post-truth>. Accessed on: April 28th, 2018.
} 
Bruno Latour had already sounded the alarm, realizing that the critical perspective of science was being co-opted by political and economic interests diametrically opposed to those who developed it, saying that "[...] the danger would no longer be coming from an excessive confidence in ideological arguments posturing as matters of fact [...] but from an excessive distrust of good matters of fact disguised as bad ideological biases", adding: "Why does it burn my tongue to say that global warming is a fact whether you like it or not?" (LATOUR, 2004, p. 222).

This issue was further explored by McGarity and Wagner in a book dedicated specifically to dissecting the deliberate distortion of science. They analyzed two specific paths of distortion: on the one hand, faking research to reach a desired result: "[w]hile philosophers and sociologists of science may debate some of the precise qualities that define science, they all agree that research conducted with a predetermined outcome is not science" (MCGARITY; WAGNER, 2008, p. 7). On the other hand, the deliberate destabilization of established science creating the appearance of a controversy where none exists, characterizing what Latour called a "manufactroversy" (a portmanteau of "manufactured controversy"):

Challenges financed and managed by advocates are also not aimed at facilitating the emergence of a scientific consensus around an established truth. To the contrary, they are meant to prolong the perception of dissensus both within and outside the scientific community. (McGARITY; WAGNER, 2008, p. 135).

As Collins and Evans argue in their most recent book, science is under attack on several fronts:

The attacks on science come from many sources. From the outside, science is beset by post-modernist analysis that sees no truth, only "accounts"; it is beset by environmentalist critiques that see science as an instrument of ecological disaster; and it is beset by political regimes that see value only in economic terms, or, in America, can make political capital by contrasting science unfavourably with religion. (COLLINS; EVANS, 2017, p. 17).

These authors also consider that science is under attack from the inside, by the strategy of certain scientists to link its defense to the production of material and cultural goods, allied to capitalism, warning that " $[t]$ he danger is that soon science will be valued only for its material and entertainment value." (COLLINS; EVANS, 2017, p. 18).

The attack on scientific credibility to advance certain agendas is not a new fact, especially with regard to public health. This was (is?) the paradigmatic strategy 
of the tobacco industry, for example, for decades (CAMARGO JR, 2012). More recently, the expansion of the "health market", the frontier of health imperialism (CAMARGO JR, 2013), found on the Internet a powerful publicity vehicle, spreading interventions (preventive or therapeutic) ranging from comic to horrifying - such as "therapeutic" proposals for autism based on the ingestion of industrial bleach (NISSE et al., 2010); from the useless to the dangerous, with growing legions of adepts increasingly hostile to scientific discourse - a particularly disturbing example is the growth of anti-vaccine all over the world, levered by the Internet (CAMARGO JR; GRANT, 2015).

In addition, the disbelief in science is particularly damaging at times such as we are living in Brazil - and in many other countries - where resources for research and technological development become increasingly scarce due to the austerity policies' economic myopia. The attempt to seek allies among the general population through public mobilizations such as the "March for Science" unfortunately does not seem to be reaching the repercussion that would be necessary. ${ }^{2}$

The disqualification of science makes it easier to restrict its funding, but both movements are estuaries of various reasons, which produce this unfortunate situation. Here we would like to focus on an aspect that seems strategically relevant and, we hope, solvable, the relative social isolation of the scientific enterprise, embodied by the metaphor of the "ivory tower". While we have been encouraged to publish more and more, which undeniably has positive aspects, such incentives have produced unforeseen - and undesirable - effects. On the one hand, the emphasis on competition between groups and individuals leads to the concentration of resources, making it difficult to establish co-operative and coordinated actions, going against the very grain of the scientific ethos, as identified by Merton's classic acronym CUDOS: communism, universalism, disinterest, organized skepticism (MERTON, 1973). It is worth remembering that Collins and Evans, in the work already cited, defend the idea that science's merits, and therefore the core of its defense strategy, lie in its shared values (including those defined by Merton), and not in its methods or results

\footnotetext{
2 "Pesquisadores denunciam situaçáo crítica em 2a Marcha Pela Ciência no Brasil" (Researchers denounce critical situation in $2^{\text {nd }}$ March for Science in Brazil). Available at: <http://portal.sbpcnet.org.br/ noticias/pesquisadores-denunciam-situacao-critica-em-2a-marcha-pela-ciencia-no-brasil/>. Accessed on: April 29 2018.
} 
(COLLINS; EVANS, 2017). On the other hand, the encouragement of publication emphasizes the dialogue of scientists with their peers, leaving the population at large relegated, at best, to a second thought. It is undeniable that the task of disseminating science faces peculiar challenges in our country; how to think of "science literacy" in a country that has not adequately given access to quality basic education to its population? In any case, the difficulty cannot be a justification for inaction.

In conclusion, the delegitimization of science has enabled, on the one hand, withholding indispensable public resources for research, increasingly linking its funding to "market" values; on the other hand, the proliferation of bizarre conceptions - "flat earth", for example - many of which are potential threats to the health of populations. The confrontation of these problems requires a strategy of forming internal alliances within science, between scientists, and external ones, with the population in general, which demands a considerable investment in the task of translation between the language of science and the language of common use, finally making Souza Santos' proposal true. This means among other things revising of the "publish or perish" logic and a return to the core values of the scientific enterprise as defined by Merton.

\section{References}

BACHELARD, G. La formation de L'Esprit Scientifique. Paris: Vrin, 1967.

CAMARGO JR, K. R. How to identify science being bent: The tobacco industry's fight to deny second-hand smoking health hazards as an example. Social Science \& Medicine, v. 75, n. 7, p. 1230-1235, 2012.

CAMARGO JR, K. R. de. Medicalização, farmacologização e imperialismo sanitário/ Medicalization, pharmaceuticalization, and health imperialism. Cadernos de saude publica, v. 29, n. 5, p. 844-846, 2013.

CAMARGO JR, K.; GRANT, R. Public health, science, and policy debate: being right is not enough. American Journal of Public Health, v. 105, n. 2, p. 232-235. doi: 10.2105/ AJPH.2014.302241, 2015.

COLLINS, H.; EVANS, R. Why democracies need science. New Jersey: John Wiley \& Sons, 2017.

LATOUR, B. Why has critique run out of steam? From matters of fact to matters of concern. Critical inquiry, v. 30, n. 2, p. 225-248, 2004.

MCGARITY, T. O.; WAGNER, W. E. Bending science: How special interests corrupt public health research. Cambridge (Mass): Harvard University Press, 2008. 
MERTON, R. K. The Normative Structure of Science. In: . The sociology of science: Theoretical and empirical investigations. Chicago: University of Chicago press, 1973.

NISSE; P.; GUYODO, G.; MANEL, J. Evaluation des risques liés à la consommation de produit dénommé "Solution Minérale Miracle" (MMS). Paris: Association Française des Centres Antipoison et de Toxicovigilance. Available at: <http://www.centres-antipoison.net/CCTV/ Rapport_CCTV_Solution_minerale_miracle_2010.pdf>. Accessed on: 3 jun 2017, from, 2010. SOUSA SANTOS, B. de. Introdução a uma ciência pós-moderna. Porto: Ediçóes Afrontamento, 1989. 